\title{
NUTM2A Gene
}

National Cancer Institute

\section{Source}

National Cancer Institute. NUTM2A Gene. NCI Thesaurus. Code C101098.

This gene has an unknown function. 